\title{
Provitamin A carotenoids content and bioaccessibility in the modified local diet for children aged 6-23 months in Bukoba, Tanzania
}

\author{
${ }^{*}$ Mbela Domina Esther Nkuba ${ }^{1 / 2}$ Kinabo Joyce ${ }^{2}$, Mwanri Akwilina Wendelin ${ }^{2}$ and Ekesa \\ Beatrice $^{3}$
}

\author{
${ }^{1}$ Mikocheni Agricultural Research Institute, PO Box 6226 Dar es Salaam, Tanzania \\ ${ }^{2}$ Sokoine University of Agriculture, Department of Food Technology Nutrition and Consumer Sciences, PO Box 3006 , \\ Morogoro, Tanzania \\ ${ }^{3}$ Bioversity International, Plot 106, Katalima Road, P.O. Box 24384, Kampala, Uganda \\ *Corresponding Author's Email: dominankuba@yahoo.com or dominankuba2013@gmail.com, Mobile: +255754749382,
} Tel+255-22 2700552 Fax: 255-222-775549

\begin{abstract}
Dietary diversification is one of the strategies to address nutrient deficiencies. The study modified eight diets for children aged 6-23 months in order to improve diversify; vitamin A content and its bioaccessibility. All samples were analysed in triplicates. Three carotenes; all-trans $\alpha$-carotene, $13-c i s-\beta$ carotene and all-trans $\beta$-carotene were determined by High Performance Liquid Chromatography. Bioaccessibility was assessed using invitro bio-accessibility model in three phases; simulated gastrointestinal system oral, gastric and intestinal. The analysed provitamin A Carotenoids (pVACs) were converted into 'Retinol Activity Equivalents' (RAE), and determined total RAE of the modified diets ranged from 8.8 to $137.4 \mu \mathrm{g} / 100 \mathrm{~g}$, and after in-vitro digestion ranged from 0.87 to $13.3 \mu \mathrm{g} / 100 \mathrm{~g}$. The bioaccessibility of pVACs ranged from $12.2 \%$ to $33.6 \%$. In cooked food, pumpkin fruit contributed high amount of provitamin A followed by palm oil, 'Bira' and amaranths. 'Bira' banana variety contributed high pVACs than local 'Nshakala' banana variety. pVACs from pumpkins leaves were more accessible than those from amaranths and red palm oil fruit. Our results suggests that when carrying out interventions to improve diets, it is very important to take into account the estimation of dietary source of vitamin A and pVCAs and their bio-accessibility to meet nutritional requirements for vitamin A.
\end{abstract}

Keywords: Diet modification, recipes, children, vitamin A, bioaccessibility

\section{INTRODUCTION}

Dietary modification is one of the strategies to address nutrient deficiencies by increasing nutrient adequacy intake. Vitamin $A$ is an essential nutrient though needed in small amounts by humans body, it plays a vital role on the normal functioning of the visual system; growth and development; and maintenance of epithelial cellular integrity, immune function, and reproduction. The dietary needs for vitamin A are normally provided as preformed retinol from animal source and provitamin $A$ carotenoids
(pVACs) from plant sources. Provitamin A carotenoids are usually converted to the active forms (retinol) to be used by the body (Bailey et al., 2015; FAO, 2004). Apart from preventing vitamin A deficiency, carotenoids rich foods protects human bodies against chronic diseases including cancers, cardiovascular disease, diabetes, cataracts, some inflammatory diseases, and age-related muscular degeneration due to their antioxidant properties (Englberger et al., 2003; Englberger et al., 2004; 
172 Afr. J. Food Sci. Technol.

Table 1. Food recipes and their ingredients used in the study

\begin{tabular}{|c|c|c|}
\hline Recipe name & Recipe code & Food Ingredients in the Recipe \\
\hline $\begin{array}{l}\text { Banana purée 'Nshakala' } \\
\text { dry bean }\end{array}$ & $1 \mathrm{~N}$ & $\begin{array}{l}\text { EAHB 'Nshakala' variety, dry red kidney beans, amaranths, palm oil, salt, onion, } \\
\text { tomatoes, bitter tomatoes }\end{array}$ \\
\hline $\begin{array}{l}\text { Banana purée 'Nshakala' } \\
\text { fresh bean }\end{array}$ & $2 \mathrm{~N}$ & $\begin{array}{l}\text { EAHB 'Nshakala' variety, fresh red kidney beans, pumpkin leaves, sunflower oil, } \\
\text { salt, onion, tomatoes, bitter tomatoes }\end{array}$ \\
\hline $\begin{array}{l}\text { Banana purée 'Bira' dry } \\
\text { bean }\end{array}$ & 2B & $\begin{array}{l}\text { AAB 'Bira' variety, dry red kidney beans, amaranths, palm oil, salt, onion, tomatoes, } \\
\text { bitter tomatoes }\end{array}$ \\
\hline $\begin{array}{l}\text { Banana purée 'Bira' fresh } \\
\text { bean }\end{array}$ & 4B & $\begin{array}{l}\text { AAB 'Bira' variety, fresh red kidney beans, pumpkin leaves, sunflower oil, salt, onion, } \\
\text { tomatoes, bitter tomatoes }\end{array}$ \\
\hline $\begin{array}{l}\text { 'Katogo'/'matoke' katogo'or } \\
\text { 'matoke' is a local recipe } \\
\text { prepared from banana, } \\
\text { beans and other }\end{array}$ & $5 \mathrm{~N}$ & \\
\hline $\begin{array}{l}\text { ingredients } \\
\text { purée }\end{array}$ & & $\begin{array}{l}\text { EAHB 'Nshakala' variety, pumpkin fruit, groundnuts flour, salt, onion, tomatoes, } \\
\text { bitter tomatoes }\end{array}$ \\
\hline $\begin{array}{l}\text { Orange-fleshed } \\
\text { potato porridge }\end{array}$ & $\begin{array}{l}\text { 6OFSP is } \\
\text { orange fleshed } \\
\text { sweet potato } \\
\text { rich in vitamin } \\
\mathrm{A} \text {; kabode } \\
\text { variety }\end{array}$ & Fermented maize flour, orange fleshed sweet potatoes, groundnut flour, sugar \\
\hline 'Bira' porridge & 7B & Fermented maize, AAB 'Bira' variety, groundnut flour, sugar \\
\hline Egg porridge & $8 \mathrm{E}$ & Fermented maize flour, egg, red kidney beans, sugar \\
\hline
\end{tabular}

Etcheverry et al., 2012; Nagao, 2009). The most common six provitamin $A$ carotenoids include $\beta$-carotene (the carotenoid with the most provitamin A activity), $\alpha$ carotene and $\beta$-cryptoxanthin (McLaren and Frigg, 2001). Other three carotenoids which cannot be converted to retinol are lutein, zeaxanthin, and lycopene (Mezzomo and Ferreira, 2016). The absorption of pVACs by the body depends on its availability. Bioavailability is the fraction of ingested nutrients that is available for utilization in normal physiological functions and/or for storage, while Bio-accessibility is the amount of nutrient released from the food matrix in the gastrointestinal tract and accessible for absorption (Etcheverry et al., 2012).

Vitamin A deficiency (VAD) during infancy can cause long-term health problems that cannot be reversed even with adequate intake later in life (Ekesa et al., 2011; Grantham-McGregor et al., 2007). These deficiency increases the severity of infections such as measles and diarrhea disease in children (NBS, 2016). VAD affects over two billion people worldwide (Bailey et al., 2015; Detzel and Wieser, 2015). In Tanzania, about one third of children below five years of age are vitamin A deficient (NBS, 2016). Particularly in Kagera region $47 \%$ of children below five years of age are vitamin A deficient (ICF-Macro, 2011; NBS, 2016). Interventions to address VAD include high-dose vitamin A capsule distributed to children (NBS, 2011) and, to a lesser extent, vitamin A fortified-foods such as, vegetable oil and fats, and flour (Hotz, 2012). Complementary foods are expected to bridge the gaps in energy and nutrients between daily requirements for children and the amount consumed. The most reliable and sustainable source of vitamin A in children is through dietary intake. However, many children are always fed from monotonous starch based diet with limited vitamin A rich foods. Godson (2014) conducted a control study, in Bukoba district in Kagera region and observed that local diets prepared with banana and bean had low vitamin A content $(44 \mu \mathrm{g}$ $\mathrm{RAE} / 100 \mathrm{~g}$ ) which is far below the recommended daily allowance (RDA) for children below five years of age for vitamin $A$ of $400 \mu \mathrm{gRAE} /$ day (recommended safe intake level) (Dewey, 2003; FAO, 2004). The amount is also below the Estimated Average Requirement (EAR) of $210 \mu \mathrm{gRAE} /$ day (Dewey, 2003). This clearly showed the importance of complementary food with micronutrients source to contribute to the nutrient requirements of children. This study used participatory dietary modification strategy to modify eight food recipes by diversifying the food ingredients per recipe to increase level and intake of vitamin A. The availability of Provitamin A and its bio-accessibility from the eight modified food recipes from plant sources was determined.

\section{MATERIALS AND METHODS}

Eight food recipes including five banana-based from EAHB 'Nshakala' Nshakala' is East African Hybrid Banana (EAHB) local variety and AAB 'Bira' 'Bira' is triploid hybrid of Musa acuminata and Musa balbisiana 
(AAB) varieties, and three maize-based porridges were developed in combination with other ingredients (Table 1), to improve diversity of food items in order to enhance intake of vitamin A were used in this study.

\section{Study Area}

Dietary modification was conducted in Izimbya ward of Bukoba district in Kagera region of Tanzania. The region is located in the north-western Tanzania, west of Lake Victoria. The main farming system in the study area is banana farming system integrated with coffee and other annual crops.

\section{Sample Preparation and Processing}

The food ingredients were purchased from the local market at Izimbya ward, Tanzania. They were properly packaged in an aerated carton and air-freight to the department Food Science and Biotechnology at BOKU University in Vienna, Austria for laboratory analysis. Triploid hybrid of Musa acuminata and Musa balbisiana (AAB) 'Bira' variety were obtained from neighboring country, Burundi, because no mature fruit bunches were available in Tanzania at the time sample collection. The banana varieties were transported on the morning of the harvest from Burundi to Kampala, Uganda where they were air-freight to Vienna, Austria within 48hrs of harvest.

On arrival at BOKU laboratory, all food samples were stored in a cold room maintained at $4^{\circ} \mathrm{C}$ for 24 hours. The recipes were prepared and cooked according defined procedures (Mbela et al., 2017 -In press). Sunflower cooking oil was added during cooking to increase bioaccessibility of provitamin A. All food samples and the single raw ingredients were initially freeze-dried (lyophilized) and then homogenized to a fine powder by grinding in mortar and pestle, and later stored in sealed tubes in the dark at $-24^{\circ} \mathrm{C}$ until analysis. Invitro digestion was carried out as described in Ekesa et al., (2013).

\section{Analysis of the Improved Recipes for Children of Age 6-23 Months}

\section{Pro-vitamin A Carotenoids Extraction}

Carotenoids extraction was done in five banana and two porridge recipes; $0.5 \mathrm{~g}$ of each freeze-dried sample was weighed into a flask and added with $2 \mathrm{ml}$ of trans- $\beta$-apo8 '-carotenal (internal standard) and $15 \mathrm{ml}$ of petroleum ether $(0.1 \%$ butylated hydroxytoluene; BHT). The flask was then shaken for 60 seconds and centrifuged for 5 $\mathrm{min}$ at $1100 \mathrm{rpm}$ (revolutions per minute). The supernatant was filtered through a funnel stuffed with glass wool and collected in a flask and added with $10 \mathrm{ml}$ of petroleum, then was added with $5 \mathrm{ml}$ petroleum ether for the following extraction steps until the supernatant was clear. A rotary evaporator was used to vaporize the petroleum ether.

To eliminate existing lipids the remaining extract was dissolved in $1 \mathrm{ml}$ ethyl-acetate and frozen at $-2^{\circ} \mathrm{C}$ for $3-4$ hours, then added with $1 \mathrm{ml}$ of frozen acetone and the liquid sample was filtered through a funnel stuffed with glass wool to separate fat from the carotenoids (Gleize et al., 2012; Rodriguez-Amaya and Kimura, 2004). The filtered sample was filled into a vial and stored at $-24^{\circ} \mathrm{C}$ under argon before the analysis; storage did not exceed 48 hours.

\section{Pro-vitamin A Carotenoid Analysis}

The whole process leading to pVACs analysis was carried out as fast as possible using alluminium foiled covered following Rodriguez-Amaya Kimura (2004) protocol. This is because carotenoids are very sensitive to light and oxygen and exposure to light leads to transcis isomerisation and destruction of pVAC.

\section{High-performance Liquid Chromatography (HPLC)}

A linear gradient elution was used for HPLC analysis. The mobile phase consisted of eluent $A$; acetonitrile (containing $0.05 \%$ triethylamine (TEA), and eluent $\mathrm{B}$; $0.1 \%$ BHT) and methanol: ethyl acetate $(1: 1, \mathrm{v} / \mathrm{v}$, containing $0.05 \%$ TEA, $0.1 \% \mathrm{BHT}$ ). Flow rate was set at $1000 \mu \mathrm{l} / \mathrm{min}$ and the injection volume was $25 \mu \mathrm{l}$. TEA was added to ensure a slightly improved peak resolution (Davey et al., 2006). For quantification of the carotenoids a calibration curve was established. Five standard solutions with different concentrations containing trans- $\beta$ apo-8'-carotenal as internal standard (IStd) and $\beta$ carotene as external standard (EStd) were prepared.

\section{Preparation of standards}

Internal standard (IStd) was prepared by weighing $5 \mathrm{mg}$ of trans- $\beta$-apo-8'-carotenal into a $100 \mathrm{ml}$ flask and filled up to volume with acetone $(0.1 \%$ BHT). Then $5 \mathrm{ml}$ of IStd solution was transferred to a $50 \mathrm{ml}$ flask and diluted with acetone $(0.1 \% \mathrm{BHT})$ to the volume. For the preparation of the external standard (EStd), $2.5 \mathrm{mg}$ of $\beta$-carotene were weighed into a $50 \mathrm{ml}$ flask and filled up to volume with acetone $(0.1 \% \mathrm{BHT})$. Then $4 \mathrm{ml}$ of EStd solution were collected, transferred to a $25 \mathrm{ml}$ flask and diluted with acetone $(0.1 \% \mathrm{BHT})$ to volume. 
Identification of carotenoids was based on the characteristics in absorption spectrum and retention time (compared to the added standards) of different carotenoids (Davey et al., 2006). Chromquest 5.0 Software was used for the interpretation of the chromatograms. Values of peak areas were used to calculate the carotenoid contents. The areas under the curve ratios between trans- $\beta$-apo-8'-carotenal as internal standard and the compounds were used for the determination of concentrations (Courraud et al., 2013). Calculations were carried out using Microsoft Office Excel 2007. The analysis was done in triplicates.

\section{Carotenoid Contents and Daily Vitamin A Recommended Dietary Allowance (RDAs) for Children}

Different pVACs are converted in the body to vitamin A (retinol) with different efficiencies. Thus, to determine the relative vitamin $A$ nutritional content of samples, total pVACs contents were first converted to all-trans $\beta$ carotene equivalents (t-BCEs) using the formula $t$ $B C E=0.5 t-A C+t-B C+0.53 c-B C$, where $c-B C$ is the sum of 13 -cis $\beta$-carotene and 13-cis $\alpha$-carotene. These values were then converted into 'Retinol Activity Equivalents' (RAE) assuming that 1/12th of the total tBCEs

ingested are taken up into the body (Yeum and Russell, 2002). The RAE in $\mu \mathrm{g} / 100 \mathrm{gfw}$ were compared to the vitamin A RDls (Ekesa et al,. 2013).

\section{Determination of Provitamin A Carotenoids bio- accessibility of the improved recipes}

\section{Invitro digestion}

The invitro bio-accessibility model was based on previous studies (Ekesa et al., 2012; Patted, 2010) with slightly modifications from this study. To mimic the human digestion, the model was divided into three phases; of oral, gastric and intestinal phase. Triplicate food samples were subjected to simulated oral, gastric and intestinal phase of digestion. For each freeze-dried food sample $1.3 \mathrm{~g}$ was weighed in a flask and filled up with water to $5 \mathrm{~g}$ and mixed with $6 \mathrm{ml}$ of saliva solution (containing $0.521 \mathrm{~g}$ $\mathrm{NaHCO} 3$ (99.5\%), $0.087 \mathrm{~g} \mathrm{NaCl}(99.5 \%), 0.048 \mathrm{~g} \mathrm{KCl}$ (99.5\%), 0.044g CaCl2. $\mathrm{H} 2 \mathrm{O}$ (97\%), 0.104g K2HPO4, $0.216 \mathrm{~g}$ mucin and 200 units $/ \mathrm{ml}$ of porcine a-amylase in $100 \mathrm{ml}$ of ultrapure water). The $\mathrm{pH}$ of the saliva solution was adjusted to $7 \pm 0.2$ by adding $1 \mathrm{M} \mathrm{NaOH}$. The mixture of saliva and food sample was incubated by shaking at $200 \mathrm{rpm}$ for $10 \mathrm{~min}$ at $3^{\circ} \mathrm{C}$. The food samples were then mixed with $15 \mathrm{ml}$ saline solution $(0.9 \% \mathrm{NaCl})$ and again incubated for $10 \mathrm{~min}$ at $37^{\circ} \mathrm{C}$ while shaking at $200 \mathrm{r} \mathrm{pm}$. To simulate the gastric digestion of an infant, $\mathrm{pH}$ of the food sample was adjusted to $4 \pm 0.2$ by adding $1 \mathrm{M} \mathrm{HCl}$. After which $2 \mathrm{ml}$ of porcine pepsin $(40 \mathrm{mg} / \mathrm{ml}$ in $0.1 \mathrm{M}$ $\mathrm{HCl}$ ) were added to acidify the food sample. For the next step to ensure activity of enzymes, $2 \mathrm{ml}$ of porcine pepsin $(40 \mathrm{mg} / \mathrm{ml}$ in $0.1 \mathrm{M} \mathrm{HCl})$ were added (Ekesa et al., 2012). Pepsin, which is responsible for the digestion of proteins, needs an acidic milieu and loses its activity at a $\mathrm{pH}=>5$ (Etcheverry et al., 2012). The mixture (homogenate) was again incubated on a shaking apparatus for 30min at $3^{\circ} \mathrm{C}$ and $200 \mathrm{rpm}$. To simulate the intestinal digest ion step, the $\mathrm{pH}$ of the partially digested mixture was first raised to $6 \pm 0.2$ by adding $0.45 \mathrm{M}$ sodium bicarbonate. Subsequently, $9 \mathrm{ml}$ of a mixture containing porcine pancreatin and bile extracts $(2 \mathrm{mg} / \mathrm{ml}$ porcine pancreatin, $12 \mathrm{mg} / \mathrm{ml}$ bile extracts in $0.1 \mathrm{M}$ trisodium citrate) and $4 \mathrm{ml}$ of bile extracts $(0.1 \mathrm{~g} / \mathrm{ml}$ in $0.1 \mathrm{M}$ trisodium citrate) were added (Ekesa et al., 2012). Bile extracts act as emulsifiers (Etcheverry et al., 2012). The food samples mixture was again incubated on a shaking apparatus for $30 \mathrm{~min}$ at $37^{\circ} \mathrm{C}$ and $200 \mathrm{rpm}$ to complete the digestion process. The digested samples were transferred to centrifugation tubes, and micelles were separated by centrifugation at $11000 \mathrm{rpm}$ for 1 hour at $10^{\circ} \mathrm{C}$. This speed was sufficient to clarify the suspension and enable micro filtration. The resulting aqueous fraction was filtered through a $0.2 \mu \mathrm{m}$ filter using a vacuum flask. Aliquots $(10 \mathrm{ml})$ of the resulting aqueous fraction were collected (pipette) into a pyrex tube. Aliquots were stored at $-24^{\circ} \mathrm{C}$ under nitrogen prior to analysis (Etcheverry et al., 2012; Gautam et al., 2010).

\section{Extraction and HPLC Analysis Extraction}

Three (3) $\mathrm{ml}$ of a trans- $\beta$-apo-8'-carotenal (50 $\mu \mathrm{g} / \mathrm{L})$ was added to the aliquot $(10 \mathrm{ml})$ and $15 \mathrm{ml}$ of hexane/ethanol $(2: 1)$ were used for the extraction. The digested sample and the solvent was briefly centrifuged for 3min at 11000 rpm and the supernatant transferred into a flask (Ekesa et al., 2012). This step was repeated three times. The collected solution was vaporized using a rotary evaporator, the remaining carotenoids were dissolved in $1 \mathrm{ml}$ ethylacetate, filtered through a pipette stuffed with glass wool and sodium sulphate, filled in vials and stored at $-24^{\circ} \mathrm{C}$ until analysis.

\section{Bio-accessibility of Pro Vitamin A analysis}

For bio-accessibility analysis, samples were injected, analysed by HPLC and calculated as described above. After digestion the amount of carotenoids in the samples (bioaccessible fraction) was expected to be lower than in 
Table 2. Provitamin A Carotenoids (pVACs) in Raw Food Ingredients $\mu / 100 \mathrm{~g}$

\begin{tabular}{|c|c|c|c|c|c|c|c|c|c|}
\hline Food item & $\begin{array}{l}\text { a carotene } \\
\text { (SD) }\end{array}$ & $\mu / 100 \mathrm{~g}$ & $\begin{array}{l}\text { All trans } \beta \\
\text { Carotene (SD) }\end{array}$ & $\mu / 100$ & $\mathbf{g}$ & $\begin{array}{l}13 \text { cis } \underset{\beta}{\beta} \mu / 100 \mathrm{~g} \\
\text { carotene }(S D)\end{array}$ & $\begin{array}{l}\text { Total } \\
\mu / 100 \mathrm{~g}\end{array}$ & pVAC & $\begin{array}{l}\text { Total RAE in } \mu \mathrm{g} / 100 \mathrm{~g} \\
\mathrm{fw}\end{array}$ \\
\hline OFSP & $6743(904)$ & & $118(5.9)$ & & & $0.0(0.0)$ & 6861 & & 290 \\
\hline Pumpkin fruit & $1377(28.6)$ & & 2066(69.1) & & & $131(5.0)$ & 3574 & & 235 \\
\hline Egg & $0.0(0.0)$ & & $17.2(3.8)$ & & & $0.0(0.0)$ & 17.2 & & 1.4 \\
\hline Amaranths & $7.1(0.0)$ & & $377(13.3)$ & & & $42.5(0.9)$ & 427 & & 33.5 \\
\hline Pumpkin leaves & $8.4(0.6)$ & & $228(4.3)$ & & & $27.1(1.2)$ & 263 & & 20.4 \\
\hline Fresh red kidney bean & $0.0(0.0)$ & & $6.6(0.5)$ & & & $0.0(0.0)$ & 6.6 & & 0.6 \\
\hline Bitter tomato ('entongo') & $3.7(0.7)$ & & $49.7(3.2)$ & & & $0.0(0.0)$ & 53.4 & & 4.3 \\
\hline Palm oil fruit & 4986(334) & & 4205(288) & & & $502(30.2)$ & 9693 & & 579 \\
\hline EAHB 'Nshakala' & $840(7.0)$ & & $426(17.8)$ & & & $26.9(0.4)$ & 1282 & & 71.2 \\
\hline AAB 'Bira' & $1716(1.0)$ & & $1930(54.9)$ & & & $96.6(1.2)$ & 3712 & & 234 \\
\hline Tomato & $7.8(0.1)$ & & $504(2.0)$ & & & $23.3(0.3)$ & 535 & & 43.3 \\
\hline
\end{tabular}

$\widehat{\mathrm{SD}}=$ Standard deviation

undigested samples, therefore standards for the calibration curve were diluted 1:10. Bioaccessibility was calculated using the following formula:

bioaccessibility $(\%)=\frac{\text { content of bioaccessible fraction }(\mu \mathrm{g} / 100 \mathrm{~g})}{\text { total content of nutrient }(\mu \mathrm{g} / 100 \mathrm{~g})} * 10 \mathrm{C}$

\section{Statistical Analysis}

Statistical analyses were performed using GenStat 14th Edition software. Means separation was done by Turkey mean separation test using Least Significant Differences (LSD) at $p \leq 0.05$. Differences in mean content of total and individual provitamin A carotenoids observed following analysis were tested using one way analysis of variance (ANOVA). Microsoft Excel 2007 was used to compute data.

\section{RESULTS}

Provitamin A Carotenoids (pVACs) Content in single raw ingredients

Provitamin A carotenoid contents (pVACs) were derived from all the recipes and presented by three pVACs: all-trans $\alpha$-carotene (t-AC), all-trans $\beta$-carotene (t-BC) and 13-cis- $\beta$-carotene. Of all the recipes, palm oil had high amount of provitamin A carotenoids of 579RAE/100g followed by orange fleshed sweet potato (291RAE/100 g), pumpkin fruit (235RAE/100g) and the least was AAB 'Bira' variety (234RAE/100 g) (Table 1). Triploid hybrid banana Musa acuminata and Musa Balbisiana (AAB), 'Bira' variety had high amount of pVAC (234 RAE/100g) than EAHB 'Nshakala' (71.2 RAE/100g) local variety. For the analysed green leaves, amaranths showed higher amount of provitamin A carotenoids of $33.5 \mathrm{RAE} / 100 \mathrm{~g}$ compared to pumpkin leaves with 20.4RAE/100g (Table 2). 
176 Afr. J. Food Sci. Technol.

Table 3. pVACs Content (in 100g) in the Optimized (modified) Diets for Children Aged 6 -23 months in Bukoba Rural

\begin{tabular}{|c|c|c|c|c|c|c|}
\hline Recipes & $\begin{array}{l}\alpha \text { carotene } \mu / 100 \mathrm{~g} \\
\text { (SD) }\end{array}$ & $\begin{array}{l}\text { All trans } \beta \text { carotene } \\
\mu / 100 \mathrm{~g}(\mathrm{SD})\end{array}$ & $\begin{array}{l}13 \text { cis } \beta \\
\text { carotene } \mu / 100 \mathrm{~g} \\
\text { (SD) }\end{array}$ & $\begin{array}{l}\text { Total } \\
\mu / 100 \mathrm{~g}\end{array}$ & pVAC & $\begin{array}{l}\text { Total RAE } \\
\mu \mathrm{g} / 100 \mathrm{gfw}\end{array}$ \\
\hline $\begin{array}{l}\text { Banana purée 'Nshakala' dry bean }(\mathbf{1 N}) \text { : EAHB 'Nshakala' variety, } \\
\text { dry red kidney beans, amaranths, palm oil, salt, onion, tomatoes, } \\
\text { bitter tomatoes }\end{array}$ & $472(3.6)$ & $451(39.4)$ & $19.0(3.7)$ & 942 & & 58.1 \\
\hline $\begin{array}{l}\text { Banana purée 'Nshakala' fresh bean }(2 \mathrm{~N}) \text { : EAHB 'Nshakala' } \\
\text { variety, fresh red kidney beans, pumpkin leaves, sunflower oil, salt, } \\
\text { onion, tomatoes, bitter tomatoes }\end{array}$ & $359(6.6)$ & $350(9.9)$ & $8.4(1.4)$ & 718 & & 44.5 \\
\hline $\begin{array}{l}\text { Banana purée 'Bira' dry bean(3B): AAB 'Bira' variety, dry red } \\
\text { kidney beans, amaranths, palm oil, salt, onion, tomatoes, bitter } \\
\text { tomatoes }\end{array}$ & $581(33.2)$ & $793(75.6)$ & $29.9(22.2)$ & 1404 & & 91.6 \\
\hline $\begin{array}{l}\text { Banana purée 'Bira' dry bean(3B): AAB 'Bira' variety, fresh red } \\
\text { kidney beans, pumpkin leaves, sunflower oil, salt, onion, tomatoes, } \\
\text { bitter tomatoes }\end{array}$ & $86.1(2.2)$ & 197(20.8) & $3.7(0.4)$ & 286 & & 20.1 \\
\hline $\begin{array}{l}\text { Katogo purée }(5 \mathrm{~N}) \text { : EAHB 'Nshakala' variety, pumpkin fruit, } \\
\text { groundnuts flour, salt, onion, tomatoes, bitter tomatoes }\end{array}$ & $870(30.7)$ & 1096(222) & $234(15.1)$ & 2200 & & 137 \\
\hline $\begin{array}{l}\text { Orange-fleshed sweet potato porridge (6OFSP): Fermented } \\
\text { maize flour, orange fleshed sweet potatoes, groundnut flour, sugar }\end{array}$ & $55.8(7.6)$ & $219(27.3)$ & $0.0(0.0)$ & 275 & & 20.6 \\
\hline $\begin{array}{l}\text { Bira' porridge (7B): Fermented maize, AAB 'Bira' variety, groundnut } \\
\text { flour, sugar }\end{array}$ & $49.7(2.7)$ & $67.1(4.3)$ & $27.8(4.3)$ & 145 & & 8.8 \\
\hline $\begin{array}{l}\text { Egg porridge (8E): Fermented maize flour, eggs red kidney beans, } \\
\text { sugar }\end{array}$ & $0.0(0.0)$ & 13.1(1.3) & $0.0(0.0)$ & 13.1 & & $1.1^{*}$ \\
\hline
\end{tabular}

*100 g of egg has 227.0RE $\mu \mathrm{g}$ which meet 56.8\%RDA vitamin A (Miranda et al., 2015); SD=Standard deviation

\section{Contribution of Modified Diets to Carotenoids Recommend Daily Allowances (RDAs) of Children Aged 6-23 Months}

The potential of the modified diets to contribute to nutritional requirements of children aged $6-23$ months is shown in Table 2. Recipe $5 \mathrm{~N}$ had the highest content of pVACs with 137.4RAE $/ 100 \mathrm{~g}$ followed by recipe $3 \mathrm{~B}$ and $1 \mathrm{~N}$ with 91.6 and 58.1 $\mathrm{RAE} / 100 \mathrm{~g}$, respectively. Recipe $5 \mathrm{~N}$ had pumpkin fruit, EAHB 'Nshakala' variety as the main source of vitamin $A$ while recipe $3 B$ had red palm oil, $A A B$
'Bira' variety and amaranths as the main source of vitamin A. Red palm oil, EAHB 'Nshakala' variety and amaranths were also the main source of vitamin $A$ in recipe $1 \mathrm{~N}$. Recipe $5 \mathrm{~N}$ had high beta $(1096 \mu \mathrm{g} / 100 \mathrm{~g})$ and alpha $(870 \mu \mathrm{g} / 100 \mathrm{~g})$ carotene content followed by recipe $3 \mathrm{~B}$ with bet 
Nkuba et al. 177

Table 4. Means of carotenoid (in the form of beta, alpha and 13-cis) content in the 8 modified recipes

\begin{tabular}{|c|c|c|c|}
\hline \multicolumn{2}{|c|}{ Pro-vitamin A carotenoids (pVACs) $\mu \mathrm{g} / \mathbf{1 0 0 g}$} & \multicolumn{2}{|c|}{ Pro-vitamin A \% bio-accessibility } \\
\hline Recipe & Mean & Recipe & Mean \\
\hline $5 \mathrm{~N}$ beta & $1096.3^{\mathrm{a}}$ & 4B alpha & $20.1^{\mathrm{a}}$ \\
\hline $5 \mathrm{~N}$ alpha & $870.0^{\mathrm{b}}$ & 6OFSP beta & $18.9^{\mathrm{a}}$ \\
\hline 3B beta & $793.0^{\mathrm{b}}$ & 6OFSP alpha & $18.3^{\mathrm{ab}}$ \\
\hline 3B alpha & $581.3^{\mathrm{c}}$ & 3B alpha & $16.4^{\mathrm{abc}}$ \\
\hline $1 \mathrm{~N}$ alpha & $472.2^{\text {cd }}$ & 3B beta & $14.2^{\mathrm{bcd}}$ \\
\hline $1 \mathrm{~N}$ beta & $451.1^{\mathrm{cd}}$ & $4 \mathrm{~B}$ beta & $13.6^{\text {cde }}$ \\
\hline 2N alpha & $359.0^{\text {de }}$ & 2N beta & $12.4^{\text {cdef }}$ \\
\hline $2 \mathrm{~N}$ beta & $350.3^{\text {def }}$ & 7B beta & $11.5^{\mathrm{def}}$ \\
\hline $5 \mathrm{~N} 13-\mathrm{cis}$ & $234.1^{\text {efg }}$ & 7B alpha & $11.2^{\text {def }}$ \\
\hline 6OFSP beta & $219.2^{\text {efgh }}$ & $1 \mathrm{~N}$ alpha & $9.64^{\text {efg }}$ \\
\hline 4B beta & $196.5^{\text {tghi }}$ & $5 \mathrm{~N}$ beta & $8.27^{\mathrm{fg}}$ \\
\hline 4B alpha & $86.2^{\text {ghij }}$ & $1 \mathrm{~N}$ beta & $6.75^{\mathrm{g}}$ \\
\hline 7B beta & $67.1^{\mathrm{hij}}$ & $2 \mathrm{~N}$ alpha & $6.01^{9}$ \\
\hline 6 OFSP13-cis & $55.8^{\mathrm{ij}}$ & $5 \mathrm{~N}$ alpha & $5.93^{9}$ \\
\hline 7B alpha & $49.6^{\prime \prime}$ & 4B 13-cis & $0.00^{n}$ \\
\hline 3B 13-cis & $29.9^{j}$ & 3B 13-cis & $0.00^{\mathrm{h}}$ \\
\hline 7B13-cis & $27.8^{\mathrm{j}}$ & $2 \mathrm{~N} 13$-cis & $0.00^{\mathrm{h}}$ \\
\hline $1 \mathrm{~N} 13$-cis & $19.0^{\mathrm{j}}$ & $1 \mathrm{~N} 13$-cis & $0.00^{h}$ \\
\hline $8 \mathrm{E}$ beta & $13.1^{j}$ & $5 \mathrm{~N} 13$-cis & $0.00^{h}$ \\
\hline $2 \mathrm{~N} 13-\mathrm{cis}$ & $13.1^{j}$ & 6OFSP 13-cis & $0.00^{\mathrm{h}}$ \\
\hline 2N13-cis & $8.4^{j}$ & 7B 13-cis & $0.00^{h}$ \\
\hline 4B13-cis & $3.7^{\mathrm{j}}$ & $8 \mathrm{E} 13$-cis & $0.00^{\mathrm{h}}$ \\
\hline 6OFSPalpha & $0.0^{\mathrm{j}}$ & $8 \mathrm{E}$ alpha & $0.00^{h}$ \\
\hline 8E13-cis & $0.0^{1}$ & $8 \mathrm{E}$ beta & $0.00^{\mathrm{h}}$ \\
\hline $8 \mathrm{E}$ alpha & $0.0^{\mathrm{j}}$ & & \\
\hline
\end{tabular}

Means in the same column with the same letter are not significantly different

$(793 \mu \mathrm{g} / 100 \mathrm{~g})$ and alpha $(58 \mu \mathrm{g} / 100 \mathrm{~g})$ carotene content and $1 \mathrm{~N}$ with beta carotene $(451 / 100 \mathrm{~g})$ and alpha carotene $(472 \mu \mathrm{g} / 100 \mathrm{~g})$. Recipe $2 \mathrm{~N}$ and $4 \mathrm{~B}$, which had 'Nshakala'/pumpkin leaves and 'Bira'/pumpkin leaves (Table 3), respectively as source of vitamin A were lower in pVACs compared to other banana recipes. Conversely, recipe $4 \mathrm{~B}$ had slightly higher vitamin $\mathrm{A}$ compared to recipe $2 \mathrm{~N}$ due to $\mathrm{AAB}$ 'Bira' variety (234RAE/100g). For porridge recipes, recipe $7 \mathrm{~B}$ had low pVACs content (145RAE/100g The mean content of vitamin $A$ ranged from 13.1 to $1,096 \mu \mathrm{g} / 100 \mathrm{~g}$ beta, 0 to $870 \mu \mathrm{g} / 100 \mathrm{~g}$ alpha and 0 to $234 \mu \mathrm{g} / 100 \mathrm{~g}$-cis carotenes with grand mean of $249 \mu \mathrm{g} / 100 \mathrm{~g}$. The mean of $\mathrm{t}-\mathrm{BC}$ was significantly higher $1096 \mu \mathrm{g} / 100 \mathrm{~g}$ at $(\mathrm{p} \leq 0.05)$ with the overall mean of $249 \mu \mathrm{g} / 100 \mathrm{~g}$. There was a significant different between mean provitamin A carotenoids contents in recipes at $\mathrm{p} \leq 0.05$ (Table 4). The percentage recommended daily allowance (RDA) for vitamin $A$ in $100 \mathrm{~g}$ for all recipes ranged from 2.2 to $34.1 \%$ (Figure 1). Except recipe $8 \mathrm{E}$ which had egg, thus, $100 \mathrm{~g}$ of egg has 227RE $\mu \mathrm{g}$ which meet 56.8\%RDA vitamin A (Miranda et al., 2015).

\section{Recommended daily intake for children aged 6-23 months to meet daily vitamin A requirements}

The RDA for vitamin A from the modified diets in $250 \mathrm{~g}$ and $500 \mathrm{~g}$ consumption size ranged from 5.5\%-85.6\% RDA and $11.0 \%-171 \%$ RDA vitamin A, respectively (Table 5). Of the seven recipes, $5 \mathrm{~N}$ showed high amount of vitamin A in both intakes on 250 and $500 \mathrm{~g} /$ day with $85.6 \%$ and $171 \%$ RDA vitamin, respectively, it corresponds to the daily requirements. It was followed by recipe $8 \mathrm{E}$ and $3 \mathrm{~B}$, which will meet $75 \%-150 \%$ RDA vitamin $A$ and 57.2-115 RDA vitamin $A$, respectively for children.

\section{Provitamin A Carotenoids (pVACs) After in-vitro Digestion in $100 \mathrm{~g}$ of the Modified/improved Diets}

The provitamin A carotenoids (pVACs) contents of the modified recipes after invitro digestion are presented in Table 6 , as all-trans $\alpha$-carotene (t-AC), all-trans $\beta$ carotene $(\mathrm{t}-\mathrm{BC})$ and 13 -cis- $\beta$-carotene. The Amount of $\mathrm{t}$ $A C$ ranged from 5.6 to $94.7 \mu \mathrm{g} / 100 \mathrm{~g}$ and 7.7 to 112 $\mu \mathrm{g} / 100 \mathrm{~g}$ in t-BC after invitro digestion. There was no 13cis- $\beta$-caroten in all recipes after invitro digestion. After invitro digestion recipe $3 \mathrm{~B}$ showed high amount of $\mathrm{pVAC}$ $(207 \mu \mathrm{g} / 100 \mathrm{~g})$ and total RAE of $13.4 \mu \mathrm{g} / 100 \mathrm{~g}$, followed by recipe $5 \mathrm{~N}(114 \mu \mathrm{g} / 100 \mathrm{~g})$ and $1 \mathrm{~N}(75.9 \mu \mathrm{g} / 100 \mathrm{~g})$ with total $\mathrm{RAE}$ of $7.4 \mu \mathrm{g} / 100 \mathrm{~g}$ and $4.4 \mu \mathrm{g} / 100 \mathrm{~g}$, respectively. 


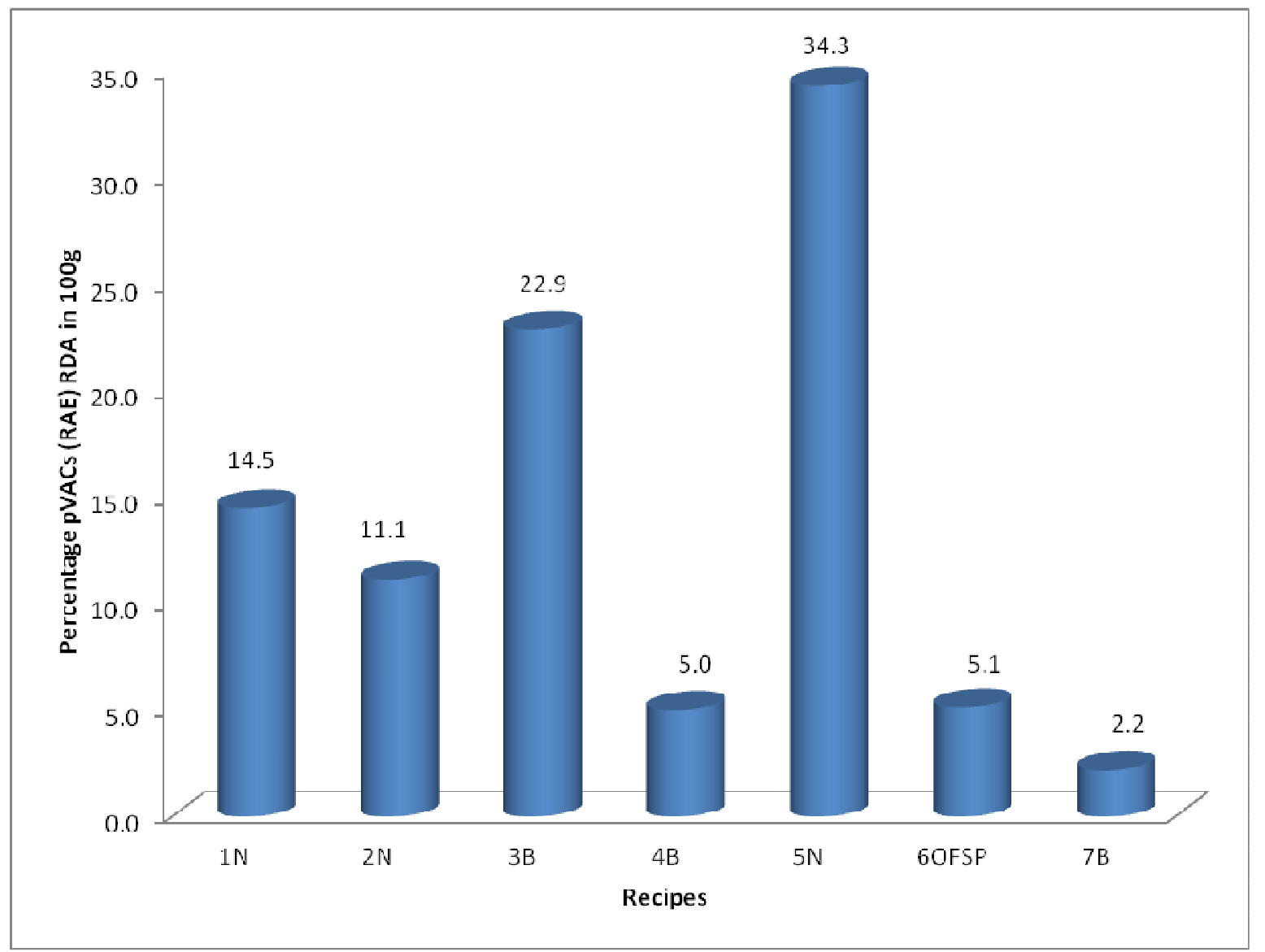

Figure 1 Percentage RDA for pVACs in 100g for children aged 6-23months in different recipes analysed in this study

However, recipe $2 \mathrm{~N}$ had slightly high amount of RAE after invitro digestion of $4.5 \mu \mathrm{g} / 100 \mathrm{~g}$ despite having total pVAC of $64.7 \mu \mathrm{g} / 100 \mathrm{~g}$. Total RAE after invitro digestion ranged from $0.87-13.3 \mu \mathrm{g} / 100 \mathrm{~g}$.

\section{Provitamin A Bioaccessibility}

Table 7 shows that the percentage bioavailability of t-AC $(20.1 \%)$ and $t-B C(16.4 \%)$ were significantly high at $\mathrm{p} \leq 0.05$ in recipe $4 \mathrm{~B}$ and $3 \mathrm{~B}$, respectively. The bioaccessibility of pVACs ranged from $12.2 \%$ to $33.6 \%$ in the modified local diets. Recipe 4B had high bioaccessibility followed by recipe $3 \mathrm{~B}$ and 6OFSP with $33.6 \%, 30.5 \%$ and $25.9 \%$, respectively. Unlike the high pVACs content in recipe $5 \mathrm{~N}$, this recipe had the least bioaccessibility followed by recipe $1 \mathrm{~N}$, which had 'Nshakala'/pumpkin fruits and 'Nshakala'/amaranths/palm oil as source of vitamin A respectively. There was significant difference between recipes in the mean percentage of pVACs bio-accessibility at $p \leq 0.05$ with grand mean of 7.2 and least significant differences (LSD) of 2.3.

\section{DISCUSSION}

\section{Provitamin A Contents in the Modified Diets}

Pro-vitamin A content varied with type of raw food in following order: palm oil, orange fleshed sweet potato (OFSP), pumpkin fruit and AAB 'Bira' variety. Of all the recipes recipe $5 \mathrm{~N}$ cooked with 'Nshakala', pumpkin fruit and groundnut had higher amounts of provitamin $A$, presumably from pumpkin fruit. Similarly, palm oil, $A A B$ 'Bira' variety and amaranths contributed high amounts of provitamin A in recipe 3B ('Bira'+ amaranths + palm oil + dry red kidney beans). This indicates that diversification of food items in a recipe can increase micronutrients content and hence intake. While pumpkin fruit was the third in pVACs contents in raw food ingredients, in 
Nkuba et al. 179

Table 5. Percentage Retinol Equivalent (RAE) RDA if $250 \mathrm{~g}$ and $500 \mathrm{~g}$ Consumed Per Day by a Child Aged Between 6 to 12 months and 12 to 23 months, Respectively.

\begin{tabular}{|c|c|c|}
\hline Recipes & $\begin{array}{l}\text { RAE \%RDA if } 250 \mathrm{~g} \\
\text { consumed /day }\end{array}$ & $\begin{array}{l}\text { RAE \%RDA if } 500 \mathrm{~g} \\
\text { consumed /day }\end{array}$ \\
\hline $\begin{array}{l}\text { Banana purée 'Nshakala' dry bean (1N): EAHB } \\
\text { 'Nshakala' variety, dry red kidney beans, amaranths, } \\
\text { palm oil, salt, onion, tomatoes, bitter tomatoes }\end{array}$ & 36.3 & 72.6 \\
\hline $\begin{array}{l}\text { Banana purée 'Nshakala' fresh bean }(2 \mathrm{~N}) \text { : EAHB } \\
\text { 'Nshakala' variety, fresh red kidney beans, pumpkin } \\
\text { leaves, sunflower oil, salt, onion, tomatoes, bitter } \\
\text { tomatoes }\end{array}$ & 27.8 & 55.6 \\
\hline $\begin{array}{l}\text { Banana purée 'Bira' dry bean(3B): AAB 'Bira' variety, } \\
\text { dry red kidney beans, amaranths, palm oil, salt, onion, } \\
\text { tomatoes, bitter tomatoes }\end{array}$ & 57.2 & 114 \\
\hline $\begin{array}{l}\text { Banana purée 'Bira' dry bean(3B): AAB 'Bira' variety, } \\
\text { fresh red kidney beans, pumpkin leaves, sunflower oil, } \\
\text { salt, onion, tomatoes, bitter tomatoes }\end{array}$ & 12.6 & 25.1 \\
\hline $\begin{array}{l}\text { Katogo purée }(5 \mathrm{~N}) \text { : EAHB 'Nshakala' variety, pumpkin } \\
\text { fruit, groundnuts flour, salt, onion, tomatoes, bitter } \\
\text { tomatoes }\end{array}$ & 85.6 & 171 \\
\hline $\begin{array}{l}\text { Orange-fleshed sweet potato porridge (6OFSP): } \\
\text { Fermented maize flour, orange fleshed sweet potatoes, } \\
\text { groundnut flour, sugar }\end{array}$ & 12.9 & 25.8 \\
\hline $\begin{array}{l}\text { Bira' porridge (7B): Fermented maize, AAB 'Bira' } \\
\text { variety, groundnut flour, sugar }\end{array}$ & 5.5 & 11.0 \\
\hline $\begin{array}{l}\text { Egg porridge ( } 8 \mathrm{E}) \text { : Fermented maize flour, egg, red } \\
\text { kidney beans, sugar }\end{array}$ & 75.0 & 150 \\
\hline
\end{tabular}

cooked recipes showed to be a good source of pVACs than other ingredients. The difference in provitamin $A$ carotenoids content was due to the retention effect after cooking. There are varieties of pumpkins, which cannot lose carotenoids while others can lose up to $22 \%$ (Ribeiro et al., 2015). Another reason could be due to high content of $\beta$-carotene in recipe $5 \mathrm{~N}$, which is the carotenoid with the most provitamin $A$ activity (McLaren, and Frigg, 2001). AAB 'Bira' variety showed to contribute high pVACs than local EAHB 'Nshakala' variety. Therefore, production and consumption of $A A B$ 'Bira' variety should be promoted to increase provitamin $A$ intake by the groups vulnerable to vitamin A deficiency.

\section{Contribution of modified diets to Daily Recommended Dietary Allowances (RDA) of Vitamin A for Children Aged 6-23 Months}

The daily requirement of the amount of complementary food for children aged $6-23$ months is $500 \mathrm{~g}$ per day and $600 \mathrm{ml}$ of breast milk consumed (Arbeit and Kouevi, 2013; Dewey et al., 2006). Other studies have documented that child aged 6 to 23 months require 600 to $674 \mathrm{ml}$ of breast milk intake per day and decreases with age (Dewey et al., 2006). Moreover, breastfed children aged 6-9 months and 9-24 months are recommended to be fed 2-3 and 3-4 meals, respectively, and all non-breastfed children 6-23 months are recommended to be fed 4-5 times a day (Berti et al., 2014; WHO, 2010). In the present study the assumption was that a child will be able to consume 250 to $500 \mathrm{~g}$ of the modified diets per day. The RDA for provitamin $A$ (retinol equivalent, $\mathrm{RE}$ ) from the modified diets of $250 \mathrm{~g}$ ranged from $5.5 \%$ to $85.6 \%$ and that of $500 \mathrm{~g}$ ranged from $11.0 \%$ to $171 \%$. The Estimated Average Requirements (EAR) for children aged 1-3 years is $210 \mu \mathrm{g} / \mathrm{d}$ (Dewey, 2003). In this regard the percentage intake from the amounts of 250 and $500 \mathrm{~g}$ will range from 10 to $163 \%$ and 21 to $326 \%$ of RDA, respectively. The 
180 Afr. J. Food Sci. Technol.

Table 6.Amount of RAE after in-vitro Digestion in 100g of Optimized (modified) Diets for Children Aged 6-23 months in Bukoba Rural

\begin{tabular}{|c|c|c|c|c|c|c|c|}
\hline Recipes & $\begin{array}{l}\alpha \quad \text { carotene } \\
\mu \mathrm{g} / 100 \mathrm{~g} \text { (SD) }\end{array}$ & $\begin{array}{l}\text { All trans } \\
\text { carotene } \\
\mu \mathrm{g} / 100 \mathrm{~g}(\mathrm{SD})\end{array}$ & $\beta$ & $\begin{array}{l}13-\text { cis- } \beta \\
\mu \mathrm{g} / 100 \mathrm{~g}\end{array}$ & carotene & $\begin{array}{l}\text { Total pVACs } \\
\mu \mathrm{g} / 100 \mathrm{~g}\end{array}$ & $\begin{array}{l}\text { Total RAE in } \\
\mu \mathrm{g} / \mathbf{1 0 0 \mathrm { g }}\end{array}$ \\
\hline $\begin{array}{l}\text { Banana purée 'Nshakala' dry bean (1N): EAHB 'Nshakala' variety, dry red kidney } \\
\text { beans, amaranths, palm oil, salt, onion, tomatoes, bitter tomatoes }\end{array}$ & $45.5(0.7)$ & $30.3(0.6)$ & & 0.0 & & 75.9 & 4.4 \\
\hline $\begin{array}{l}\text { Banana purée 'Nshakala' fresh bean ( } 2 N) \text { : EAHB 'Nshakala' variety, fresh red } \\
\text { kidney beans, pumpkin leaves, sunflower oil, salt, onion, tomatoes, bitter tomatoes }\end{array}$ & $21.5(3.6)$ & 43.2(5.0) & & 0.0 & & 64.7 & 4.5 \\
\hline $\begin{array}{l}\text { Banana purée 'Bira' dry bean(3B): AAB 'Bira' variety, dry red kidney beans, } \\
\text { amaranths, palm oil, salt, onion, tomatoes, bitter tomatoes }\end{array}$ & $94.7(9.8)$ & 112(11.1) & & 0.0 & & 207 & 13.3 \\
\hline $\begin{array}{l}\text { Banana purée 'Bira' dry bean ( } 3 B \text { ): AAB 'Bira' variety, fresh red kidney beans, } \\
\text { pumpkin leaves, sunflower oil, salt, onion, tomatoes, bitter tomatoes }\end{array}$ & 17.4(3.1) & $26.7(4.7)$ & & 0.0 & & 44.0 & 2.9 \\
\hline $\begin{array}{l}\text { Katogo purée }(5 \mathrm{~N}) \text { : EAHB 'Nshakala' variety, pumpkin fruit, groundnuts flour, salt, } \\
\text { onion, tomatoes, bitter tomatoes }\end{array}$ & $51.1(19.6)$ & $62.9(25.8)$ & & 0.0 & & 114.1 & 7.4 \\
\hline $\begin{array}{l}\text { Orange-fleshed sweet potato porridge (6OFSP): Fermented maize flour, orange } \\
\text { fleshed sweet potatoes, groundnut flour, sugar }\end{array}$ & $24.3(11.9)$ & $7.7(1.6)$ & & 0.0 & & 31.9 & 1.7 \\
\hline Bira' porridge (7B): Fermented maize, AAB 'Bira' variety, groundnut flour, sugar & $5.6(1.4)$ & $7.7(2.3)$ & & 0.0 & & 13.3 & 0.7 \\
\hline
\end{tabular}

$\mathrm{SD}=$ Standard deviation

Table 7: Bio-acessibility of pVAC of Optimized (modified) Diets for Children Aged 6-23 months in Bukoba Rural

\begin{tabular}{|c|c|c|c|c|}
\hline Recipes & $\begin{array}{l}\alpha \text { carotene }(\%) \\
\text { (SD) }\end{array}$ & $\begin{array}{l}\text { All trans } \beta \text { carotene } \\
\text { (\%) (SD) }\end{array}$ & $\begin{array}{l}\text { 13-cis- } \beta \text { carotene } \\
\text { (\%) (SD) }\end{array}$ & $\begin{array}{l}\text { Total bioaccessibility } \\
\% / 100 \mathrm{~g}\end{array}$ \\
\hline $\begin{array}{l}\text { Banana purée 'Nshakala' dry bean ( } 1 \mathrm{~N}) \text { : EAHB 'Nshakala' variety, dry red kidney beans, amaranths, palm } \\
\text { oil, salt, onion, tomatoes, bitter tomatoes }\end{array}$ & $9.6(0.1)$ & $6.7(0.5)$ & $0.0(0.0)$ & 16.4 \\
\hline $\begin{array}{l}\text { Banana purée 'Nshakala' fresh bean (2N): EAHB 'Nshakala' variety, fresh red kidney beans, pumpkin } \\
\text { leaves, sunflower oil, salt, onion, tomatoes, bitter tomatoes }\end{array}$ & $6.0(1.0)$ & $12.4(1.8)$ & $0.0(0.0)$ & 18.4 \\
\hline $\begin{array}{l}\text { Banana purée 'Bira' dry bean(3B): AAB 'Bira' variety, dry red kidney beans, amaranths, palm oil, salt, } \\
\text { onion, tomatoes, bitter tomatoes }\end{array}$ & $16.4(2.6)$ & $14.2(0.9)$ & $0.0(0.0)$ & 30.5 \\
\hline $\begin{array}{l}\text { Banana purée 'Bira' dry bean(3B): AAB 'Bira' variety, fresh red kidney beans, pumpkin leaves, sunflower } \\
\text { oil, salt, onion, tomatoes, bitter tomatoes }\end{array}$ & $20.1(3.1)$ & $13.6(1.0)$ & $0.0(0.0)$ & 33.6 \\
\hline $\begin{array}{l}\text { Katogo purée }(5 \mathrm{~N}) \text { : EAHB 'Nshakala' variety, pumpkin fruit, groundnuts flour, salt, onion, tomatoes, bitter } \\
\text { tomatoes }\end{array}$ & $5.9(2.5)$ & $6.2(3.8)$ & $0.0(0.0)$ & 12.2 \\
\hline $\begin{array}{l}\text { Orange-fleshed sweet potato porridge (6OFSP): Fermented maize flour, orange fleshed sweet potatoes, } \\
\text { groundnut flour, sugar }\end{array}$ & $11.7(7.4)$ & $14.2(5.0)$ & $0.0(0.0)$ & 25.9 \\
\hline $\begin{array}{l}\text { Bira' porridge (7B): Fermented maize, AAB 'Bira' variety, groundnut flour, sugar } \\
p \leq 0.05\end{array}$ & $11.2(2.5)$ & $11.5(3.4)$ & $0.0(0.0)$ & 22.7 \\
\hline
\end{tabular}

$\mathrm{SD}=$ Standard deviation 
mean requirement for vitamin $A$ for children aged between 7-12 and 12-36 months is 190 and $200 \mu \mathrm{gRE} /$ day (FAO, 2004). Therefore, if a child of 712 months consumes $250 \mathrm{~g}$ and of $12-36$ months $500 \mathrm{~g}$ of modified diets the intake will range from $11-180 \%$ and 22 $342 \%$, respectively.

Breast milk provides a significant portion of daily vitamin A requirement for children. Assuming an average breast-milk intake, the amount of vitamin A required from complementary food is 63RE, 92RE and 400RE for 6-8.9 months, 9-11.9 months and 12-23.9 months children, respectively (Dewey et al., 2006). Thus, all the modified diets will meet the RDA for vitamin A in children aged 6 to 23 months old and above. As reported (Carvalho et al., 2012) that food can be labeled as the 'source' of a nutrient when $100 \mathrm{~g}$ of the product provides more than $15 \%$ of the dietary reference intake for the desired nutrient. Recipe 7B fall below recommended RDA (2.2\% RDA vitamin A for recommended safe intake) as it has low percentage RDA in $100 \mathrm{~g}$ and low amount of $8.8 \mu \mathrm{RE} / 100 \mathrm{~g}$.

\section{Bioaccessibility of pVACs in the Modified/improved Diets}

The study shows that provitamin A carotenoids (pVACs) from pumpkin leaves in $4 \mathrm{~B}$ recipe were more bio-

bioaccessibility. Therefore, nutrient bioaccessibility must be considered because when RDA is high does not mean the nutrient will be $100 \%$ bio-accessible.

\section{CONCLUSION}

Chronologically palm oil fruit and orange fleshed sweet potato showed high amount of provitamin A carotenoids (pVAC's). Fresh red kidney bean and bitter tomatoes showed the least pVAC's. Recipe $5 \mathrm{~N}$ had the highest content of pVACs whereby pumpkin fruit was the main source of vitamin A. Recipe 7B had low pVACs, whereby $A A B$ 'Bira' variety was the main source of $p V A C s$. Recipe $4 \mathrm{~B}$ had high bioaccessibility. The percentage RDA for vitamin $A$ in $100 \mathrm{~g}$ for all recipes ranged from 2.2 to $34.1 \%$ for plant source while animal source porridge with egg, in $100 \mathrm{~g}$ meets $56.8 \%$ RDA vitamin A. The bioaccessibility of pVACs ranged from $12.2 \%$ to $33.6 \%$ in the modified local diets. The modified diets are good source of vitamin A for children as well as adults combating Vitamin A defficiency. Our results suggests that it is very important to take into account the estimation of dietary source of vitamin $A$ and their pVACs bioaccessibility to meet nutritional requirements of children aged 6-23 months. accessible than those from amaranths and red palm oil fruit in recipe 3B chronologically. This indicates clearly that pumpkin leaves contribute to high bio-accessibility of pVACs content, because both recipe $4 B$ and $3 B$ had $A A B$ 'Bira' variety. Red palm oil showed higher pVACs in raw food ingredients as it contains high concentrations of $\beta$ carotene (t-BC) and $\alpha$-carotene (t-AC). This also confirmed by You et al., (2002) that red palm oil contain high vitamin A value. However, the low bio-accessibility of red palm oil was demonstrated in this study when red palm oil was added in recipe $3 \mathrm{~B}$ and recipe $1 \mathrm{~N}$, it could not significantly increase the bioaccessibility of pVACs, hence confirmation for low bioaccessibility of red palm oil. Thus, provitamin A carotenoids bioaccessibility is not determined by pVACs contents rather is determined by food variety. Furthermore, all the recipes had oil to improve micellarization of carotenoids. For porridge recipe, recipe 6OFSP with orange fleshed sweet potato the total pVACs were more bioaccessible than AAB 'Bira' variety in recipe $7 \mathrm{~B}$. Recipe $5 \mathrm{~N}$ with pumpkin fruit and 'Nshakala' as source of pVACs showed to have high amount of RAE but its bioaccessibility was very low compared to other recipes. This indicates that pVACs in pumpkin fruit had low bioaccessibility compared to pVACs in pumpkin leaves and AAB 'Bira' variety. Thus, production and consumption of pumpkin leaves should be encouraged to enhance intake of vitamin $A$. To translate vitamin $A$ requirements into recommendations for daily dietary intakes requires an estimate of vitamin $A$

\section{ACKNOWLEDGEMENTS}

The authors acknowledge Sokoine University of Agriculture, Tanzania for technical support and Bioversity International for funding the study. Support from the Ministry of Agriculture, Tanzania, Local Government Authority, Bukoba Rural District Council of Kagera region, farmers and participants are equally acknowledged.

\section{REFERENCES}

Arbeit B, Kouevi K (2013). A Study on Moringa Oleifera Leaves as a Supplement to West African Weaning Foods. Humburg University of Applied Science, West Africa.

Bailey RL, West JrKP, Black RE (2015). The Epidemiology of Global Micronutrient Deficiencies. Annals of Nutrition and Metabolism, 66(Suppl. 2), 22-33.

Berti C, Faber M, Smuts C (2014). Prevention and Control of Micronutrient Deficiencies in Developing Countries: Current Perspectives. Nutrition and Dietary Supplements, 6, 41-57.

Carvalho LM, Corrêa MM, Pereira EJ, Nutti MR, Carvalho JL, Ribeiro EM, Freitas SC (2012). Iron and Zinc Retention in Common Beans (Phaseolus vulgaris L.) After Home Cooking. Food and Nutrition Research, 56.

Courraud J, Berger J, Cristol JP, Avallone S (2013). Stability and Bioaccessibility of Different Forms of Carotenoids and Vitamin A During invitro Digestion. Food Chem. 136(2):871-877. 
182 Afr. J. Food Sci. Technol.

Davey MW, Keulemans J, Swennen R (2006). Methods for the Efficient Quantification of Fruit Provitamin A Contents. Journal of Chromatography A, 1136(2), 176-184.

Detzel P, Wieser S (2015). Food Fortification for Addressing Iron Deficiency in Filipino Children: Benefits and Cost-effectiveness. Annals of Nutrition and Metabolism, 66(Suppl. 2), 35-42.

Dewey K (2003). Guiding Principles for Complementary Feeding of the Breastfed Child.

Dewey K, Cohen R, Arimond M, Ruel M (2006). Developing and Validating Simple Indicators of Complementary Food Intake and Nutrient Density for Breastfed Children in Developing Countries.

Ekesa B, Blomme G, Garming H (2011). Dietary Diversity and Nutritional Status of Pre-school Children from Musa-dependent Households in Gitega (Burundi) and Butembo (Democratic Republic of Congo). Afr. J. Food, Agric, Nutr. and Dev. 11(4).

Ekesa B, Kimiywe J, Van den Bergh I, Blomme G, Dhuique-Mayer C, Davey M (2013). Content and Retention of Provitamin A Carotenoids Following Ripening and Local Processing of Four Popular Musa Cultivars from Eastern Democratic Republic of Congo. Sustainable Agriculture Research, 2(2), 60

Ekesa B, Poulaert M, Davey MW, Kimiywe J, Van den Bergh I, Blomme G, Dhuique-Mayer C. (2012). Bioaccessibility of Provitamin A Carotenoids in Bananas (Musa spp.) and Derived Dishes in African Countries. Food Chem. 133(4), 1471-1477.

Englberger L, Darnton-Hill I, Coyne T, Fitzgerald MH, Marks GC (2003). Carotenoid-rich Bananas: a Potential Food Source for Alleviating vitamin A deficiency. Food and Nutrition bulletin, 24(4), 303-318.

Englberger L, Marks G, Fitzgerald M (2004). Factors to Consider in Micronesian Food-based Interventions: A Case Study of Preventing Vitamin A Deficiency. Public health nutrition, 7(03), 423-431.

Etcheverry P, Grusak MA, Fleige LE (2012). Application of invitro Bioaccessibility and Bioavailability Methods for Calcium, Carotenoids, Folate, Iron, Magnesium, Polyphenols, Zinc, and Vitamins $B_{6}, B_{12}, D$, and E. Frontiers in physiology, Vol. 3, Article 317

FAO (Food and Agriculture Organization) (2004). Vitamin and mineral requirements in human nutrition. Second edition. Report of a Joint FAO/WHO Expert Consultation. Rome: Food and Agriculture Organisation

Gautam S, Platel K, Srinivasan K (2010). Influence of $\beta$-carotene-rich Vegetables on the Bioaccessibility of Zinc and Iron from Food Grains. Food chem. 122(3), 668-672.

Gleize B, Steib M, André M, Reboul E (2012). Simple and Fast HPLC Method for Simultaneous Determination of Retinol, Tocopherols, Coenzyme Q 10 and Carotenoids in Complex Samples. Food Chem. 134(4), 2560-2564.

Grantham-McGregor S, Cheung YB, Cueto S, Glewwe P, Richter L, Strupp B, Group ICDS (2007). Developmental Potential in the First 5 Years for Children in Developing Countries. The lancet, 369(9555), 60-70.

Hotz CL, de Brauw A, Eozenou P, Gilligan D, Moursi M, Munhaua B, van Jaarsveld P, Carriquiry A Meenakshi JV (2012). A large-scale Intervention to Introduce Orange Sweet Potato in Rural Mozambique Increases Vitamin A Intakes Among Children and Women. British J. Nutr. 108(1), 163-176.

ICF-Macro (2011). Micronutrients: Results of the 2010 Tanzania Demographic and Health Survey. Dar es Salaam: NBS and ICF Macro.
Mbela DEN, Kinabo J, Mwanri A, Ekesa B (2017). Modification of Local Diets to Improve Vitamin A, Iron and Protein Content for Children Aged 6 to 23 Months. Afr. J. Food, Agric. Nutr. and Dev. (AJFAND) (17025), 22-In press

McLaren DS, Frigg M ( 2001). Sight and Life Manual on Vitamin A Deficiency Disorders (VADD). 233(4), 345-390. doi: 0067

Mezzomo N, Ferreira SRS (2016). Carotenoids Functionality, Sources, and Processing by Supercritical Technology: A Review. J. Chem.

Miranda JM, Anton X, Redondo-Valbuena C, Roca-Saavedra P, Rodriguez JA, Lamas A, Cepeda, A (2015). Egg and Egg-derived Foods: Fffects on Human Health and Use as Functional Foods. Nutrients, 7(1), 706-729.

Nagao, A. (2009). Absorption and Function of Dietary Carotenoids Food Factors for Health Promotion (Vol. 61, pp. 55-63): Karger Publishers.

NBS (National Bureau of Statistics) and ICF Macro. (2011). Tanzania Demographic and Health Survey 2010. Dar es Salaam, Tanzania: NBS and ICF Macro. 451pp.

NBS (National Bureau of Statistics) and ICF Macro. (2016). Tanzania Demographic and Health Survey and Malaria Indicator Survey (TDHS-MIS) 2015-16. Dar es Salaam, Tanzania: NBS and ICF Macro. 591pp.

Patted MV (2010). Bioaccessibility of Iron and Zinc from Green Leafy Vegetable Based Products. (Master of Home Science in Food science), University of Agricultural Sciences, Dharwad

Ribeiro EMG, Chitchumroonchokchai C, de Carvalho LMJ, de Moura FF, de Carvalho JLV, Failla ML (2015). Effect of Style of Home Cooking on Retention and Bioaccessibility of pro-vitamin A Carotenoids in Biofortified Pumpkin (Cucurbita moschata Duch). Food Research International, 77, 620-626.

Rodriguez-Amaya D.B. Kimura M. (2004). Harvest Plus Handbook for Carotenoid Analysis. Harvest Plus Technical Monograph 2.

WHO (2010). Indicators for Assessing Infant and Young Child Feeding Practices. Part 3: Country Profiles. World Health Organization.

Yeum KJ, Russell RM (2002). Carotenoid Bioavailability and Bioconversion. Annual Review of Nutrition, 22(1), 483-504.

You CS, Parker RS, Swanson JE (2002). Bioavailability and Vitamin A Value of Carotenes from Red Palm Oil Assessed by an Extrinsic Isotope Reference Method. Asia Pacific J. Clinical Nutr. 11(s7), S4 38-S442. 